\title{
The Effect of Workplace Spirituality on Work Commitment Through Personality (Study on Nurses in Maluku Province)
}

\author{
O L Sahertian ${ }^{1}$, M Setiawan ${ }^{2}$, Sunaryo $^{3}$ \\ \{oliviasahertian@yahoo.com ${ }^{1}$ \} \\ Universitas Brawijaya, Indonesia ${ }^{1,2,3}$
}

\begin{abstract}
Workplace spirituality is crucial in an organization and cannot be separated from individual behavior. It is also a new area in research. Individual behavior is related to human personality. This research contributes to the relation of individual spirituality in the organization. The purpose of this research is to analyze the influence of workplace spirituality on work commitment mediated by personality. This research is an explanatory research with a quantitative approach utilizing a survey method. Population in this research was nurses in type B public hospitals in Maluku Province, Regional General Hospital dr. Haulussy and Level II Hospital Prof. dr. J.A. Latumeten, with a sample of 184 nurses. Data were analyzed using the SEM-PLS method. The research results exhibited that workplace spirituality influences personality, workplace spirituality influences work commitment, and personality influences work commitment. This research also found that personality mediated the influence of workplace spirituality on work commitment.
\end{abstract}

Keywords: Public Health, Work Commitment, SEM-PLS

\section{Introduction}

Workplace spirituality is one of the important values for individuals in an organization [1] [2] and it is inseparable from an organization [3] [4]. Workplace spirituality is a new area of research [5]. Research on workplace spirituality is new research or at an early stage [6] and needs to be developed extensively [4]. In its development, spirituality is recognized as a fundamental part of the research [2], and for many decades there has been much attention from researchers [3]. Workplace spirituality influences work behavior [8], one of which is commitment. In management, commitment is the main variable, which explains that individuals who are committed would perform to the best of their ability. C[8]ommitment plays an important role in the philosophy of human resources [9]. Employees who are committed have a strong desire to remain a member of the organization and accept values in the organization to be part of the organization [10]. Several studies that prove that workplace spirituality affects commitment [5] [8] [11]. Spiritual values are related to an individual and one's personality. Individuals in an organization differ from one another and are crucial resources in achieving organizational goals. Individual differences are prioritized in management science and organizational behavior for an important reason, it have a direct impact on behavior [12]. 
Health organizations are a vital tool in a country, one of which is a hospital. The hospital must provide a sense of usefulness and meaningfulness for internal hospitals [13]. The nurse is one of the health providers in the hospital and is inseparable from the hospital. In practice, based on the phenomenon and the fact that many problems faced by the hospital. Patient dissatisfaction with the performance of medical personnel in providing health services. This also occurs in hospitals in Maluku province. Some of the phenomena that occur in hospitals and residents complaints involved the performance of medical personnel such as medical officers. Many complaints were made by the community regarding hospital medical services. Whereas if it is associated with the value of spirituality it is very contradictory. This exhibits the behavior of nurses who are not in accordance with what they should and reflect the lack of commitment of nurses in carrying out their duties. Based on the description above, the purpose of this study is to analyze the influence of workplace spirituality on work commitment and mediated by the personality of nurses in hospitals in Maluku province.

\section{Research Hypothesis and Variable Measurement}

\subsection{Hypothesis Development}

Workplace spirituality is crucial in an organization and employees are needed to behave in their workplace [22]. Research conducted by [8] [5] [11] [23] [24] found that workplace spirituality influences commitment. Based on the description above, the following hypothesis was formulated, H1: Workplace spirituality influences work commitment. Workplace spirituality is related to individual behavior. Empirical studies prove that spirituality influences the personality of an individual [25] [26]. Furthermore, it was explained by [27] that personality influences individual behavior. Based on this statement, the following hypothesis was formulated, H2: Workplace spirituality influences personality. Personality affects individual behavior. Empirical studies conducted by [27] [28] [29] found that personality influences organizational commitment. Based on this explanation, the following hypothesis was formulated, H3: Personality influences work commitment. Workplace spirituality affects commitment [8] [11] [23] [24]. Individual personality also influences organizational commitment [27] [28] [29]. Thus the following hypothesis was formulated, H4: Workplace spirituality influences work commitment mediated by personality.

\subsection{Operational Definition and Variable Measurement}

\subsubsection{Workplace spirituality}

Workplace spirituality is an exogenous variable. Workplace spirituality is the value within the individual, which then becomes the basis for behaving in the workplace. Workplace spirituality consists of three dimensions which were used to measure this variable, namely a) Inner life, b) Meaningful work, c) Community conditions [7].

\subsubsection{Personality}

Personality is an exogenous variable used in this research. Personality is a dynamic organization within an individual possessing psychological system, which determines a person's adjustment to the environment. Personality is measured by using the personality model "big five" [30], namely extraversion, agreeableness, conscientiousness, emotional stability and openness to experience.

\subsubsection{Work Commitment}


Work commitment is an endogenous variable. Work commitment is an individual's attachment to work that reflects the level of individual involvement in the work and the individual's desire to remain part of the work. Three indicators are used as a measurement of work commitment variables developed by [31] namely affective occupational commitment, continuous work commitment, and normative work commitment.

\section{Methodology and Results}

\subsection{Research Methodology}

This research is an explanatory research and using survey methods to collect data and using a quantitative approach [32]. The location of the research was in type B general hospital in Maluku Province, namely Regional General Hospital dr. Haulussy and Level II Hospital Prof. dr. J. A Latumeten. The population in this study amounted to 519 nurses, 357 nurses at the Regional General Hospital dr. Haulussy and 162 nurses at Level II Hospital Prof. dr. J. A Latumeten. Sampling process used purposive sampling with judgment sampling method. It was used because the sample must meet predetermined criteria [33]. The criteria used are: a) Permanent medical personnel; b) Working as nurse medical personnel for at least 3 years; c) Working in an inpatient room. Based on the Slovin formula, the minimum sample size is 225 . By using proportionate stratified random sampling technique, random sampling with proportional amounts for each hospital, the number of samples for RSUD dr. Haulussy is 155 people and Level II Hospital Prof. dr. J. A Latumeten is 70 people. The questionnaire processed was 189, as some respondents did not return the questionnaire and incomplete questionnaire answers. Data analysis used PLS-SEM with SmartPLS.

\subsection{Measurement Model (Outer Model)}

The outer model or measurement model defines each indicator block related to its latent variables [34]. There are three criteria for assessing the outer model, namely convergent validity, composite reliability, and discriminant validity. For convergent validity, all indicators used in this study have a loading factor greater than 0.5 and significant $(\mathrm{t}$ count $>\mathrm{t}$ table (1.96)), therefore no indicators are discarded. For discriminant validity, AVE value of each construct must be greater than 0.5. AVE value for workaplace spirituality is 0.512 , personality is 0.519 and work commitment is 0.624. All variables used in this study have composite reliability and Cronbach Alpha greater than 0.7 . The value of composite reliability for workplace spiritualiy variable is 0.95 and cronbach alpha is 0.944 , composite reliability for personality is 0.95 and cronbach alpha is 0.94 , composite reliability for work commitment variable is 0.96 and cronbach alpha 0.95 .

\subsection{Structural Model (Inner Model)}

The R-square of work commitment was 0.504 . It indicates that the workplace spirituality and personality contribute to work commitment by $50.4 \%$, while the remaining $49.6 \%$ is the contribution of other variables not examined. The picture of the relationship between variables along with the path and loading factor coefficient of each indicator is presented in Figure 1 below. 


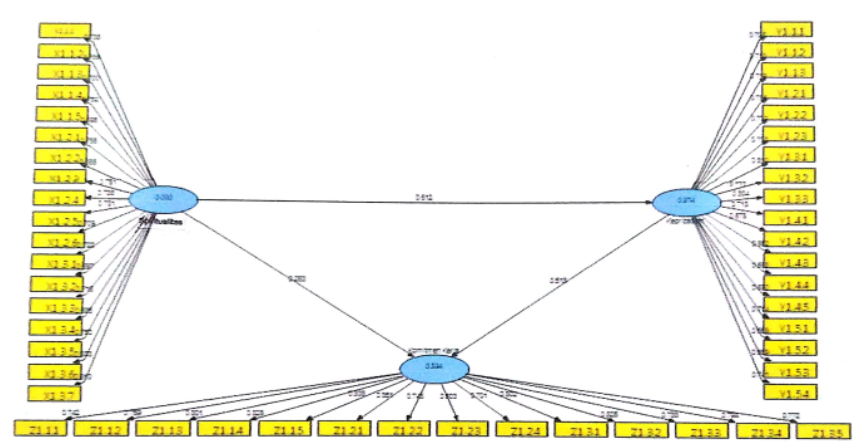

Figure 1. Value of Relationships between Variables and Indicator

Workplace spirituality variable possesses loading factor value on item X1.2.4. stating 'the importance of work' from the meaningful work indicator 0.786. It is the highest contribution to explaining the variables of workplace spirituality. This exhibits that the nurse realizes that the profession and work undertaken are important in life. Personality variable possesses the largest loading factor value on item Y13.1 stating 'works well and precisely' from the indicator of conscientiousness 0.809. It is a high contribution to explaining personality variables. This indicates that nurses work well and correctly. Work commitment variable possesses the biggest loading factor value on item Z1.2.1 stating that the nurse chooses to work as a nurse from the continuous work commitment indicator at 0.850 . This means that nurses choose a profession as a nurse. Table 1 exhibits the path coefficient and $\mathrm{t}$ test results on each latent variable which is the result of hypothesis testing.

Table 1. Hypothesis Assessment Result

\begin{tabular}{|c|l|c|c|c|}
\hline Hypothesis & \multicolumn{1}{|c|}{ Variable Correlation } & $\begin{array}{c}\text { Path } \\
\text { Coefficient }\end{array}$ & t-count & Justification \\
\hline H1 & $\begin{array}{l}\text { Workplace spiritualiy } \rightarrow \text { Work } \\
\text { commitment }\end{array}$ & 0.263 & 3.252 & Significant \\
\hline H2 & Workplace spiritualiy $\rightarrow$ Personality & 0.612 & 12.555 & Significant \\
\hline H3 & Personality $\rightarrow$ Work commitment & 0.518 & 7.016 & Significant \\
\hline H4 & $\begin{array}{l}\text { Workplace spiritualiy } \rightarrow \text { Work } \\
\text { commitment (Mediated by personality) }\end{array}$ & $0.612 \times 0.518$ & 0.580 & Significant \\
\hline
\end{tabular}

Source: Processed Data Results, 2018

The relationship between workplace spirituality and work commitment is path coefficient 0.263 , which exhibits a positive relationship. T-count value is 3.252 which is greater than $\mathrm{t}$ table (1.96), which means that workplace spirituality has a significant effect on work commitment. Thus the first hypothesis is accepted. A good workplace spirituality will increase work commitment. The relationship between workplace spirituality and personality has a path coefficient of 0.612 which exhibits a positive relationship. The t-count value is 12,555 . This means that spirituality has a significant effect on personality. Thus the second hypothesis 
which states that workplace spirituality affects personality can be accepted. Personality and work commitment relationships have a path coefficient of 0.518 which exhibits a positive relationship. The t-count value is 7,016, therefore it has a significant effect. Thus the third hypothesis which states that personality influences work commitment is accepted. The relationship between workplace spirituality and personality, personality and work commitment is positive with path coefficients of 0.612 and 0.518 . The indirect relationship of workplace spirituality and work commitment through personality possess path coefficient 0.580 . This exhibits a positive and significant influence.

\section{Discussion and Conclusions}

Spirituality is the focus of research in modern organizations and crucial for individuals in an organization. Workplace spirituality does not refer to religion, but a good and true value an individual believed. Thus it can be interpreted that workplace spirituality is a good and true inner life of individuals practiced in their work in a community context [11]. This study possesses theory and the empirical result [35] [36] [37], which states that individuals will find meaning in the activities they do and feel spiritually rich. High workplace spirituality will increase work commitment [8] [5] [11] [24] [23] [10]. A high work commitment from the nurse will have a positive impact on the hospital. Personality cannot be separated and is closely related to individual behavior [38]. A good personality will increase commitment [27]. Based on the results of this study, workplace spirituality influences work commitment. This finding is in line with research conducted by [8] [5]. However, this finding is not in line with the research conducted by [39], which stated that personality is negatively related to continuance commitment. Nurses who have high values of workplace spirituality and practice spiritual values in carrying out daily activities in serving patients have a high tendency to work commitment.

The findings also prove that workplace spirituality influences personality. These results are in line with the research of [39] [40]. Nurses who always consider good and right values underlie work by praying, appreciating their work, working joyfully will have a good impact on their personality and increase the sense of belonging to the organization. The results of the study also prove that personality influences work commitment. These findings are in line with [27] [28] [29] [41]. People who have good personalities, people who are friendly to others, work well, not temporally and creatively will increase their work commitment. A person's personality will be reflected in their attitude. A good individual person has a positive value for the individual's commitment. The research findings proved that personality mediates the influence of workplace spirituality on work commitment. Workplace spirituality affects organizational commitment and may be higher when mediated by personality. Nurses who have high spirituality values will increase their work commitment. Based on the findings of this study, hospitals in Maluku, especially RSUD dr. Haulussy and Level II Hospital Prof. dr. J. A. Latumeten can pay attention to and develop nurses important values as well as the infrastructure required to develop the nurse's personality. This is crucial to apply because it will greatly influence the attitude of the nurse itself, especially to have a high work commitment.

The limitations of this study are only using a quantitative approach. Further research may add a more in-depth qualitative approach to discussing research results, therefore it can be discussed in terms of gender. In addition, research only focuses on the dependent variable of work commitment, therefore further research can add other dependent variables, such as OCB, job satisfaction and productivity. Although there are deficiencies in this study, this research 
has contributed to filling gaps in the organizational and management literature. This study suggests organizations and leaders play an important role in increasing individual work commitment, because the consequences are organizational performance [37]. Furthermore, it can be explained that humans think rationally, but also have emotional and spiritual factors. Individuals have thoughts, inner feelings, and lives. Spirituality is a profound experience of individuals ${ }^{[11]}$ that will bring positive value to the organization.

\section{References}

[1] S. Pandey, "Workplace Spirituality: Linkages with Attitude , Mental Health , Leadership , Organizational Development, Earning Management, Stress and Wellbeing Abstract :," Int. J. Bus. Manag., vol. 2, no. 7, pp. 139-144, (2014).

[2] P. Petchsawanga, D. Duchon, and - P Petchsawanga, "Workplace Spirituality, Meditation, and Work Performance," J. Manag. Spiritual. Relig., vol. 9, no. 10, (2012).

[3] I. Faro Albuquerque Rita Campos Cunha Luís Dias Martins Armando Brito Sá, I. Faro Albuquerque Rita Campos Cunha Luís Dias Martins Armando Brito, J. Milliman, A. J. Czaplewski, J. Ferguson, B. Shankar Pawar, I. Faro Albuquerque, R. Campos Cunha, L. Dias Martins, and A. Brito Sá, "Journal of Organizational Change Management"Individual spirituality, workplace spirituality and work attitudes: An empirical test of direct and interaction effects" Primary health care services: workplace spirituality and organizational performance," J. Organ. Chang. Manag. J. Organ. Chang. Manag. Iss J. Organ. Chang. Manag. Iss Leadersh. \&amp Organ. Dev. J. Univ. Brawijaya, vol. 27, no. 18, pp. 53-75, (2014).

[4] G. Mahakud and K. Gangai, The Influence of Workplace Spirituality on Organisational Commitment Among Public Sector Sector Employees, vol. 4, no. 1. (2015).

[5] B. S. Pawar, "Individual spirituality, workplace spirituality and work attitudes: An empirical test of direct and interaction effects," Leadersh. Organ. Dev. J., vol. 30, no. 8, pp. 759-777, (2009).

[6] M. L. Sheep, "Nurturing the Whole Person : The Ethics of Workplace Spirituality in a Society of Organizations," pp. 357-375, (2006).

[7] J. Milliman, A. J. Czaplewski, and J. Ferguson, Workplace spirituality and employee work attitudes, vol. 16, no. 4. (2003).

[8] M. Armstrong, A Handbook of Human Resources Management Practice. (2009).

[9] L. Wainaina, M. Iravo, and A. Waititu, "Workplace Spirituality as a Determinant of Organizational Commitment amongst Academic Staff in the Private and Public Universities in Kenya," Int. J. Acad. Res. Bus. Soc. Sci., vol. 4, no. 12, pp. 280-293, (2014).

[10] A. Rego and M. Pine e Cunha, "Workplace spirituality and organizational commitment: an empirical study," J. Organ. Chang. Manag., vol. 21, no. 1, pp. 53-75, (2008).

[11] J. Ivancevich, R. Kanopaske, and M. Matteson, Organizational Behavior and Management. New York: MacGraw-Hill, (2011).

[12] D. Abdurrahman and P. M. Agustini, "Hubungan Kepemimpinan Spiritual dan Spiritualitas Tempat Kerja,” pp. 527-542, (1996).

[13] F. Karakas, "Spirituality and Performance in Organizations : A Literature Review," pp. 89-106, (2010).

[14] M. Mohamed and A. Ruth, "Workplace spirituality and organizational commitment: A study on the public schools teachers in Menoufia (Egypt)," African J. Bus. Manag., vol. 10, no. 10, pp. 247-255, (2016).

[15] A. Rego, M. Pina E. Cunha, and S. Souto, "Workplace spirituality, commitment, and self-reported individual performance: An empirical study," Manag. Res. J. Iberoam. Acad. Manag., vol. 5, no. 3, pp. 163-183, (2007).

[16] M. Womble, E. Labbe, and R. Cochran, "Spirituality and personality: understanding their relationship to health resilience $1, "$ pp. 706-715, (2013).

[17] K. C. Koessel and J. R. Morris, "The relationship between spirituality and personality," vol. 3492979, p. 114, (2011).

[18] D. Matsumoto, "Culture, Context , and Behavior," no. December, 2007.

[19] C. W. Hackney, "Personality, organizational commitment, and job search behavior: A field study," 
pp. $1-78,(2012)$

[20] I. Abdullah, R. Omar, and Y. Rashid, "Effect of Personality on Organizational Commitment and Employees' Performance: Empirical Evidence from Banking Sector of Pakistan," Middle-East J. Sci. Res., vol. 18, no. 6, pp. 759-766, (2013).

[21] H. M. M. L. Herath and F. A. Shamila, "The Impact of Employee Personality Traits on Organizational Commitment in an Apparel Industry in Trincomalee District," vol. 1, no. 1, pp. 111, (2018).

[22] D. P. Ashmos and D. Duchon, "Spirituality at Work: A Conceptualization and Measure," J. Manag. Inq., vol. 9, no. 2, pp. 134-145, (2000).

[23] H. He, W. Wang, W. Zhu, and L. Harris, "Service workers ' job performance The roles of personality traits , organizational," (2015).

[24] J. P. Meyer, N. J. Allen, and C. A. Smith, "Commitment to Organizations and Occupations: Extension and Test of a," vol. 78, no. 4, pp. 538-551, (1993).

[25] J. . Hair, W. . Black, B. . Babin, R. . Anderson, and R. . Tatham, Multivariate Data Analysis, Sixth Edit. New Jersey: Pearson Prentice Hall, (2006).

[26] A. Ferdinand, Metode Penelitian Manajemen. Semarang: CV Indoprint, (2014).

[27] I. Ghozali and H. Latan, Partial Least Square: Konsep, Teknik dan Aplikasi Smart PLS 2.0 M3. Semarang: Badan Penerbit Universitas Diponegoro, (2012).

[28] J. Garcia-Zamor, "Workplace spirituality and organizational performance," Public Adm. Rev., vol. 63, no. 3, pp. 355-363, (2003).

[29] R. a Giacalone and C. L. Jurkiewicz, "Toward a science of workplace spirituality," Handb. Work. Spiritual. Organ. Perform., no. October, pp. 3-28, (2003).

[30] D. Duchon and D. A. Plowman, "Nurturing the spirit at work: Impact on work unit performance," Leadersh. Q., vol. 16, no. 5, pp. 807-833, (2005).

[31] M. Hwang, "Personality traits and simultaneous reciprocal influences between job performance and job satisfaction," (2014).

[32] D. Choi, A. Colbert, and I.-S. Oh, "Understanding Organizational Commitment : A Meta Analytic Examination of The Roles of The Five-Factor Model of Personality and Culture," J. Appl. Psychol., (2015).

[33] P. Gupta, "Correlational study of individual personality differences and spirituality at workplace."

[34] T. W. Moore, "Individual Differences and Workplace Spirituality: The Homogenization of the Corporate Culture," pp. 79-93.

[35] B. C. Emecheta, H. O. A., and U. Ojiabo, "Personality Characteristics and Employee Affective," Int. J. Bus. Manag. Rev., vol. 4, no. 6, pp. 69-92, (2016). 